\title{
AVALIATION OF VENTILATORY PATTERN IN THE TOAD RHINELLA SCHNEIDERI (ANURA: BUFONIDAE)
}

\author{
FERNANDES, Marcelo dos Santos ${ }^{1}$ \\ GIUSTI, Humberto ${ }^{2}$ \\ GLASS, Mogens Lesner ${ }^{3}$
}

SUMMARY: Amphibians ventilated their lungs by buccal pumping mechanism, which was first described in 1969 as a model for studying anurans respiration. Since amphibians do not have alveoli in their lungs, we calculated to the toad Rhinella schneideri the equivalent lung ventilation from the equation $\mathrm{V}_{\mathrm{EFF}}=$ $\left(\mathrm{V}_{\mathrm{L}} \mathrm{CO}_{2} \cdot \mathrm{RT}\right) / \mathrm{P}_{\mathrm{L}} \mathrm{CO}_{2}$. We analyzed buccal and pulmonary pressures, respiratory volumes, lung and buccal ventilation, and ventilation frequency. $\left[\mathrm{V}_{\mathrm{E}}\left(12,1 \pm 0,6 \mathrm{ml} \mathrm{BTPS} \cdot \mathrm{min}^{-1} \cdot \mathrm{kg}^{-1}\right) ; \mathrm{V}_{\mathrm{EB}}\left(164,3 \pm 2,2 \mathrm{ml} \mathrm{BTPS} \cdot \mathrm{min}^{-1} \cdot \mathrm{kg}^{-}\right.\right.$ $\left.{ }^{1}\right) ; \mathrm{f}_{\mathrm{R}}\left(5,8 \pm 0,4 \mathrm{~min}^{-1}\right)$; buccal frequencies $\left(68,5 \pm 1,6 \mathrm{~min}^{-1}\right)$; Tidal volume $\left.\left(\mathrm{V}_{\mathrm{T}}=2.4 \mathrm{ml} \mathrm{BTPS} \cdot \mathrm{kg}^{-1}\right)\right]$. The low oxygen extraction $(17,3 \pm 2,8 \%)$ was used to explain the high frequency of pulmonary and buccal ventilation.

Keywords: Ventilatory pattern, Buccal volumes, Lung volumes, Ventilation pressures. Lung oxygen extraction.

RESUMO: Os anfíbios ventilam seus pulmões por meio de bombeamento bucal, mecanismo que foi primeiramente descrito 1969 como um modelo para a respiração de anuros. Como os anfíbios não possuem alvéolos em seus pulmões, foi calculado para o sapo Rhinella schneideri a ventilação equivalente do pulmão por meio da equação $\mathrm{V}_{\mathrm{EFF}}=\left(\mathrm{V}_{\mathrm{L}} \mathrm{CO}_{2} \cdot \mathrm{RT}\right) / \mathrm{P}_{\mathrm{L}} \mathrm{CO}_{2}$. Analisamos as pressões bucais e pulmonares, os volumes respiratórios, ventilação pulmonar e bucal, e frequências de ventilação. $\left[\mathrm{V}_{\mathrm{E}}\left(12,1 \pm 0,6 \mathrm{ml} \mathrm{BTPS} \cdot \mathrm{min}^{-1} \cdot \mathrm{kg}^{-1}\right) ; \mathrm{V}_{\mathrm{EB}}\right.$ $\left(164,3 \pm 2,2 \mathrm{ml} \mathrm{BTPS} \cdot \mathrm{min}^{-1} \cdot \mathrm{kg}^{-1}\right) ; \mathrm{f}_{\mathrm{R}}\left(5,8 \pm 0,4 \mathrm{~min}^{-1}\right)$; Freqüência bucal $\left(68,5 \pm 1,6 \mathrm{~min}^{-1}\right)$; volume corrente $\left(\mathrm{V}_{\mathrm{T}}\right.$ $=2,4$ BTPS $\left.\left.\mathrm{ml} \bullet \mathrm{kg}^{-1}\right)\right]$. A baixa extração de oxigênio $(17,3 \% \pm 2,8)$ foi utilizada para explicar a alta freqüência da ventilação pulmonar e bucal.

Palavras-chave: Padrão de ventilação. Volume Bucal. Volume pulmonar. Extração de oxigenio pulmonar.

\section{INTRODUCTION}

Reptiles and mammals ventilate their lungs through expansion and retraction of the chest (ROMER, 1985). The inspiration results from the contraction of specific respiratory muscles, which expand the pleural space. This generates subatmospheric pressure inside the lungs and thus the suction of air (HLASTALA; BERGER, 2001). The expiration results from

\footnotetext{
${ }^{1}$ Educational Foundation of Ituverava. Cel. Flauzino Barbosa Sandoval Street, 1259, 14500-000 Ituverava, São Paulo. Brazil. - CORRESPONDENCE: e-mail, enzopipapipa@ yahoo.com.br

2. Department of Physiology, Faculty of Medicine of Ribeirão Preto, University of São Paulo, Bandeirantes Avenue 3900, 14.049-900 Ribeirão Preto, São Paulo. Brazil.

${ }^{3}$. Department of Physiology, Faculty of Medicine of Ribeirão Preto, University of São Paulo, Bandeirantes Avenue 3900, 14.049-900 Ribeirão Preto, São Paulo. Brazil.
} 
natural retraction of elastic fibers and the surface tension of the lungs, in resting state, or active contraction of the muscles of the chest in situations of exercise (WEST, 1995).

In modern amphibians (Lissamphibia), the expiration is also apparent result from retraction of elastic and surface tension of lung tissue, however, inspiration is performed by pumping air into the lungs by positive pressure generated by coordinated movements of the buccal cavity (HUGHES, 1974). They lost their ribs in evolution (ROMER, 1985).

Amphibians' lungs develop during metamorphosis from aquatic larvae, concomitantly with the reabsorption of their gills. Thus, in adults, the lungs are responsible for amphibian's buoyancy of aquatic habits, perform gas exchange, maintenance of acid-base balance, vocalization and defensive behaviors. The lungs have a more important role in the uptake of $\mathrm{O}_{2}$ than elimination of $\mathrm{CO}_{2}$, which is conducted largely through the skin (YEAGER; ULTSCH, 1989).

The lungs of frogs are simple, with distinct parenchyma, from where bronchi short coming to the larynx, which opens to the buccal cavity through the glottis. The trachea can be undifferentiated and appear extremely short and poorly vascularized (YEAGER; ULTSCH, 1989). The lungs are large and without alveoli, extending for about $2 / 3$ of the body length.

Studies have shown that anurans have a pattern consisting of two ventilation cycles distinct: one from buccal movements, called oscillatory cycles, and another movements of pumping air into the lungs, performed by the buccal cavity, called of lung ventilation cycles. During cycles of buccal moviments, the animal is in apnea with lungs inflated and closed glottis. With the nostrils open, freely ventilate the buccal cavity, resulting in equilibrium between the gas composition intrabuccal and external. Then the animal interrupts its buccal cycles and started to present a more complex ventilatory pattern divided in five stages (DE JONGH; GANS,1969; GANS et al., 1969):

- Stage 1 - Start by contraction of the sterno-hyoid muscle, which causes further expansion of the buccal cavity. The reduction of intrabuccal pressure to subatmospheric levels causes the inspiration of outside air to the buccal cavity. The glottis is closed and retains the stored air in the lungs.

- Stage 2 - The glottis is open, allowing air to leak from the lungs into the buccal cavity. This results of retractable properties of lung tissue. There is, at this time, the equalization between intrabuccal pressures and intrapulmonary. The air that reaches the lungs to the buccal cavity is exhaled through the nostrils which remain open.

- Stage 3 - With the glottis, the air still escapes into small plots and intrapulmonary 
pressure falls below the buccal cavity. Intrabuccal pressure remains above atmospheric, resulting from the resistance imposed by the nostrils to the air outlet.

- Stage 4 - The nostrils are closed, and thus the buccal cavity, through your muscles petro-hyoid and omo-hyoid, pumping air into the lungs through the glottis which is still open. This promotes sharp increase in intrabuccal pressure and intrapulmonary.

- Stage 5 - It is the simultaneous closing of the glottis and nostrils opening, accompanied by relaxing the muscles of the mouth. There is a fall in pressure in the buccal cavity to atmospheric levels, thus restarting the cycle mouth again.

These ventilatory sequences of events described for Lithobates catesbeianus have been identified in other species of anurans, but many differences in patterns were observed (JONES, 1972; WEST; JONES, 1975; MACINTYRE; TOEWS, 1976; BRETT; SHELTON, 1979; JONES, 1982, SHELTON; BOUTILIER, 1982; BOUTILIER, 1984; KRUHØFFER et al., 1987; VITALIS; SHELTON, 1990; WANG, 1994).

We decided to study and describe the ventilatory patterns of the toad Rhinella schneideri just to contribute in a better way to understand the anuran's respiration.

\section{MATERIAL AND METHODS}

Animals and Surgical procedures.- Specimens of Rhinella schneideri with $210 \pm 25$ $\mathrm{g}$ (mean \pm SEM) were captured in Ribeirão Preto, and kept in the Department of Physiology, Faculty of Medicine of Ribeirão Preto. Were kept in tanks (250 liters) with free access to water, and fed weekly with earthworms. The animals, after being weighed, were anesthetized by skin contact with $0,5 \mathrm{~g} / 1$ of benzocaine in a container. We adopted the time of 2 hours to complete recovery and 24 hours for experiments.

A polyethylene catheter (Pe90) was introduced into the buccal cavity through the tympanic membrane and in a small portion of the right lung for the withdrawal of air samples, pressure and volume measurements.

Measures of Respiratory Variables.- Ventilation was evaluated using the technique of the mask with a pneumotachograph coupled as described for small animals by Glass et al. (1978).

The animal was kept in a box and his mask was connected by tubes to a differential pressure transducer (Validyne, model DP45-14-2114), sent to an amplifier (Validyne, Model CD15), connected to a display data acquisition ( FAC-204.A). The records of the flows were 
stored and later analyzed using the software Excel and Diaden. All experiments were performed at $25^{\circ} \mathrm{C}$ during the day.

Were calculated inspiratory and expiratory volumes (including volumes of the first expiration), tidal volume, respiratory frequencies, buccal and lung ventilation and pressures. Was maintained, with the aid of a suction pump, a flow $\left(10 \mathrm{ml} \cdot \mathrm{min}^{-1}\right)$ constant removal of air from the anterior region of the mask, thus avoiding a possible hypercapnia. As a result of intrapulmonary anatomy of toad, it was appropriate in this research called the alveolar ventilation to effective ventilation $\left(\mathrm{V}_{\mathrm{EF}}\right)$, this being obtained through the equation of alveolar ventilation (WEST, 1995):

$$
\begin{aligned}
& \mathrm{V}_{\mathrm{EF}}=\left(\mathrm{V}_{\mathrm{P}} \mathrm{CO}_{2} \cdot \mathrm{RT}\right) / \mathrm{P}_{\mathrm{A}} \mathrm{CO}_{2} ; \\
& {\left[\mathrm{V}_{\mathrm{EF}}=\mathrm{V}_{\mathrm{A}}=\text { alveolar ventilation }\left(\mathrm{ml} \text { BTPS.min }{ }^{-1} \cdot \mathrm{kg}^{-1}\right) ; \mathrm{V}_{\mathrm{P}} \mathrm{CO}_{2}=\right.\text { pulmonary }}
\end{aligned}
$$
elimination of $\mathrm{CO}_{2}\left(\mathrm{ml} \mathrm{STPD} \cdot \mathrm{min}^{-1} \cdot \mathrm{kg}^{-1}\right) ; \mathrm{P}_{\mathrm{A}} \mathrm{CO} 2=$ partial pressure of $\mathrm{CO}_{2}$ intrapulmonary $(\mathrm{mmHg}) ; \mathrm{RT}=$ gas constant $\mathrm{x}$ absolute temperature $(\mathrm{K})=2.785 .\left(273 \mathrm{~K}+25^{\circ} \mathrm{C}\right)=830 \mathrm{~mm}$ Hg. ml (ml.STPD $\left.\left.{ }^{-1}\right)\right]$

Pulmonary Extraction of Oxygen.- We used the following equations to obtain the lung extraction of oxygen described by Dejours (1981), which reports the percentage of $\mathrm{O}_{2}$ absorbed by the lung capillaries:

$\mathrm{E}_{1}=\left(\left(\mathrm{PiO}_{2}-\mathrm{P}_{\mathrm{A}} \mathrm{O}_{2}\right) / \mathrm{PiO}_{2}\right) .100 \% ; \mathrm{E}_{2}=1-\left(1-\left(\mathrm{P}_{\mathrm{A}} \mathrm{CO}_{2} /\left(\mathrm{PiO}_{2} \times \mathrm{R}_{\mathrm{E}}\right)\right) .100 \%\right.$;

$\left[\mathrm{P}_{\mathrm{I}} \mathrm{O}_{2}=\right.$ partial pressure of inspired oxygen $(\mathrm{mmHg}) ; \mathrm{P}_{\mathrm{A}} \mathrm{O}_{2}=$ partial pressure of oxygen intrapulmonary $(\mathrm{mmHg}) ; \mathrm{P}_{\mathrm{A}} \mathrm{CO}_{2}=$ partial pressure of carbon dioxide intrapulmonary $(\mathrm{mmHg}) ; \mathrm{R}_{\mathrm{E}}=$ respiratory rate $]$.

The equation E2 was used alternative only to confirm the consistency of the calculation of equation E1.

To calculate the respiratory rate we used the alveolar gas equation (West, 1995): $R_{E}=$ $\mathrm{P}_{\mathrm{A}} \mathrm{CO}_{2} /\left(145-\mathrm{P}_{\mathrm{A}} \mathrm{O}_{2}\right)$

Statistics. -The paired t test and analysis of variance one-way ANOVA followed by Bartlett's test was used. For parametric measures was used Bonferroni test, otherwise the Kruskal-Wallis test followed by Dunn. All values are expressed as mean \pm SEM $(p<0.05)$, with a total $\mathrm{n}$ of 18 animals.

\section{RESULTS}

Measures of intrabuccal and intrapulmonary pressures.- Records of intrabuccal and intrapulmonary pressures did during cycles of buccal and lung of toad Rhinella schneideri 
are shown in Figure 1, that clearly confirmed, as might be expected, the function of the buccal cavity to pump air to the lungs during the pulmonary cycle like in others anurans.

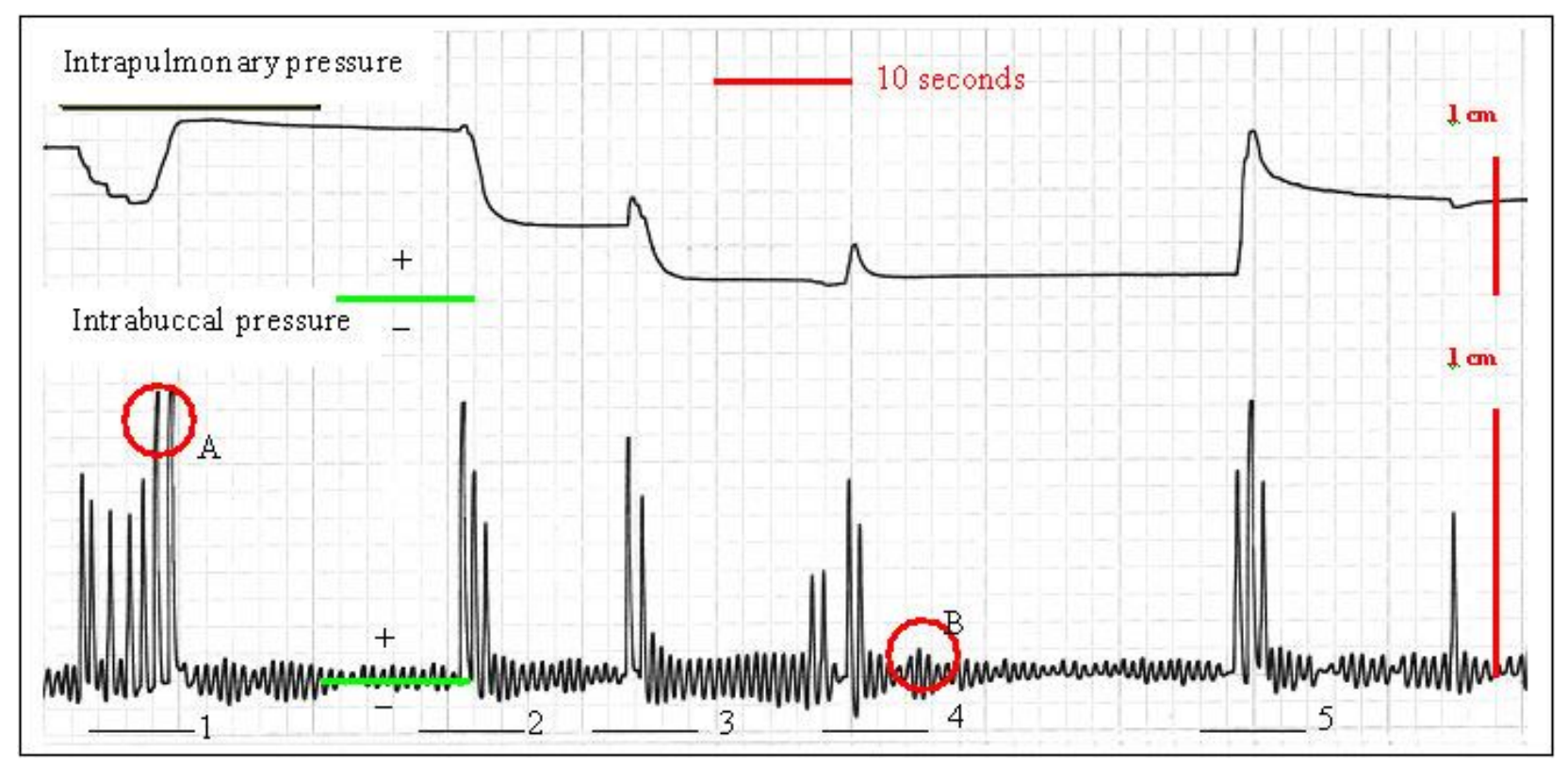

Figure 1 - Records of intrabuccal and intrapulmonary pressures during the buccal and pulmonary ventilation $\left(\mathrm{cm} \mathrm{H}_{2} \mathrm{O}\right)$. Note the difference between the intrabuccal pressures during a cycle of lung (A) and buccal (B)ventilation. During the time intervals, positioned below the records of the buccal cavity pressure is observed: (1) lung deflation followed by inflation, (2) lung deflation, (3) lung inflation followed by deflation, (4) lung inflation followed by deflation, (5) lung inflation followed by deflation. The speed of the records was $0.25 \mathrm{~cm} . \mathrm{seg}^{-1}$, during the day at $25^{\circ} \mathrm{C}$. The green horizontal bar is equivalent to atmospheric pressure $\left(1 \mathrm{~cm} \mathrm{H}_{2} \mathrm{O}\right)$.

In time interval 1 during a pulmonary cycle, there was a reduction in intrapulmonary pressure paralleled with increase in intrabuccal pressure. This means the passage of an airflow through the glottis from lungs to the buccal cavity. However, this flow was followed by an immediate buccal pumping air into the lungs, evidenced by the simultaneous increase of intrabuccal and intrapulmonary pressures. In time interval 2 there was only deflation of the lungs to the buccal cavity, which probably resulted in expiratory flow volume and higher through the nostrils, without any buccal pumping. In the interval 3 a brief inflate of lungs was accompanied by deflation of larger volume. In the interval 4, inflation accompanied by deflation of similar volume. In the time 5 a large volume was pumping from the mouth to the lungs, as evidenced by simultaneous increases of intrabuccal and intrapulmonary pressures. It is noteworthy that the inflation of the lungs occurring in successive intervals of filling or emptying in the case of deflation. The interval 5 also shows the occurrence of a leak of air 
from the lungs during cycles mouth, because there is gradual decrease of intrapulmonary pressure over time. This can also be seen in Figure 2.

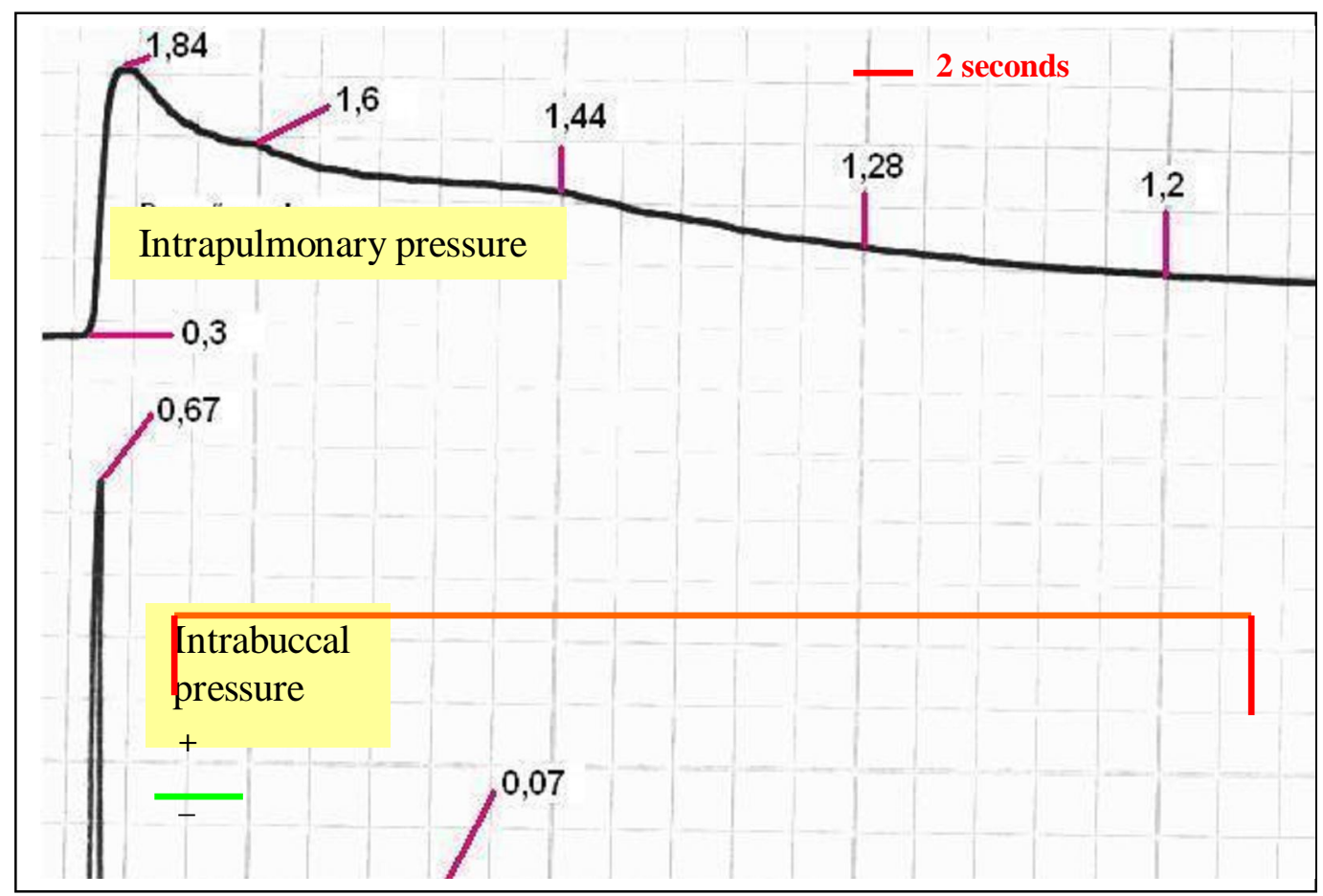

Figure 2-The record shows a buccal pump during a cycle of ventilation, as evidenced by the simultaneous increase in intrabuccal and intrapulmonary pressures $\left(\mathrm{cm} \mathrm{H}_{2} \mathrm{O}\right)$. The pressure values are indicated by numbers and arrows. Gradual decrease of intrapulmonary pressure during buccal cycles(red bar), indicating a possible leak through the glottis. The green bar is equivalent to atmospheric pressure $\left(1 \mathrm{~cm} \mathrm{H}_{2} \mathrm{O}\right)$.

Evidences that the lung inflations occur at intervals of successive fillings are observed in the records of Figure 3. Intrabuccal pressures are gradually increased and accompanied also by increasing the intrapulmonary. 


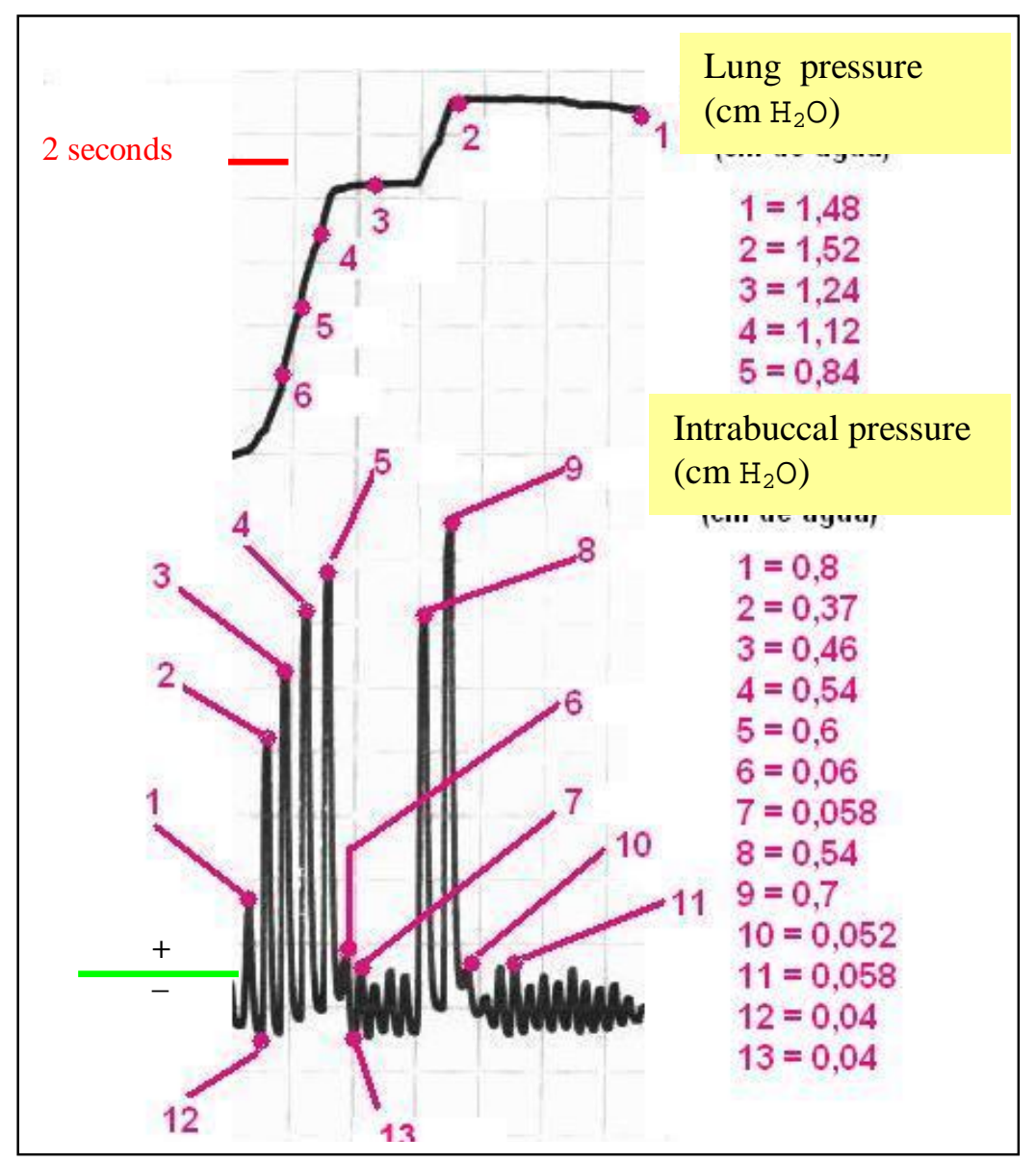

Figure 3 - The record shows a buccal pump during a cycle of lung ventilation in pulmonary inflations occur at intervals of successive fillings, as evidenced by the simultaneous increase of intrabuccal and intrapulmonary pressures $\left(\mathrm{cm} \mathrm{H}_{2} \mathrm{O}\right)$. The pressure values are indicated by numbers and arrows. The green bar is equivalent to atmospheric pressure $\left(1 \mathrm{~cm} \mathrm{H}_{2} \mathrm{O}\right)$.

The same applies to lung deflation, which shows sequence of successive reduction of intrapulmonary pressure, accompanied by increases in intrabuccal (Figure 4). 


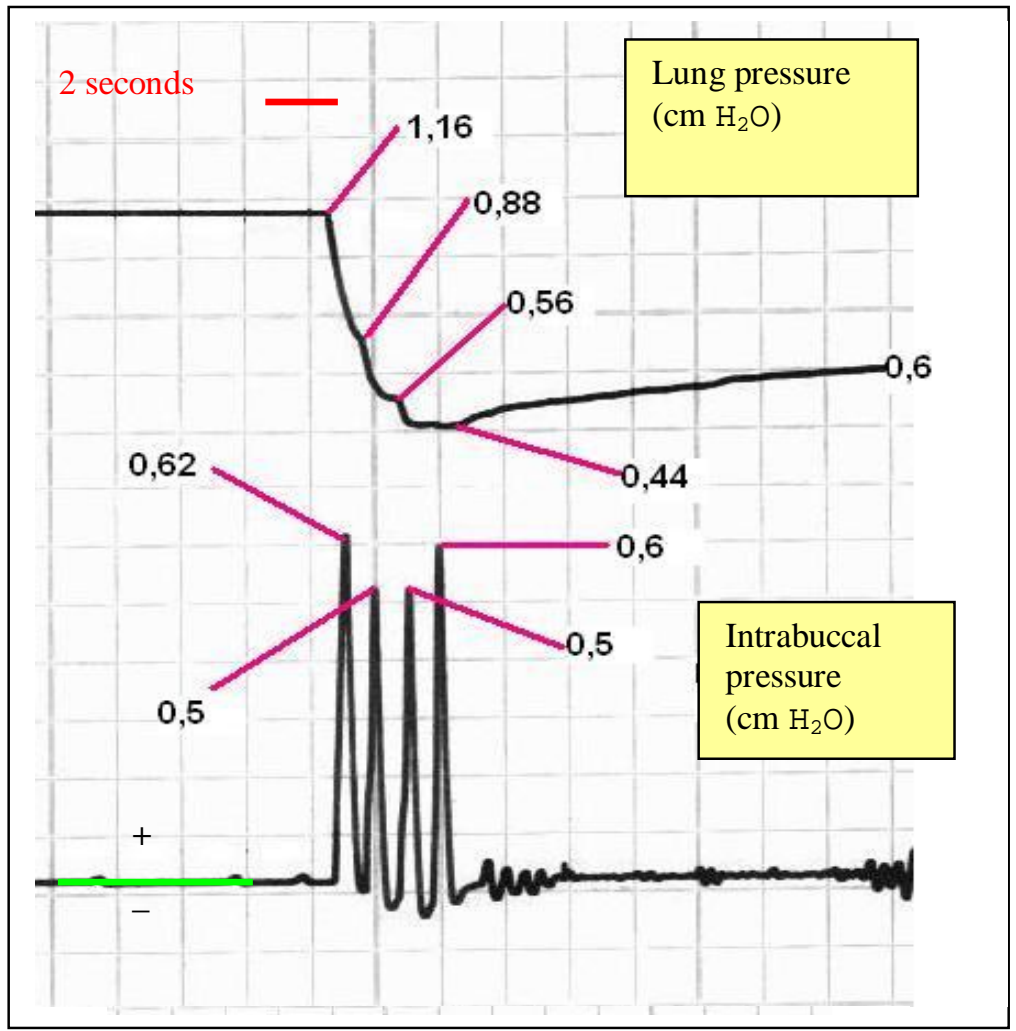

Figure 4 - The record shows a lung deflation during a cycle of ventilation, as evidenced by the decrease of intrapulmonary pressure accompanied by the simultaneous increase of intrabuccal pressure $\left(\mathrm{cm} \mathrm{H}_{2} \mathrm{O}\right)$. The pressure values are indicated by numbers and arrows. The green bar is equivalent to atmospheric pressure $\left(1 \mathrm{~cm} \mathrm{H}_{2} \mathrm{O}\right)$.

It was common in respiratory pattern observations of inflation accompanied by immediate deflation of the lungs, as can be seen in Figure 5. 


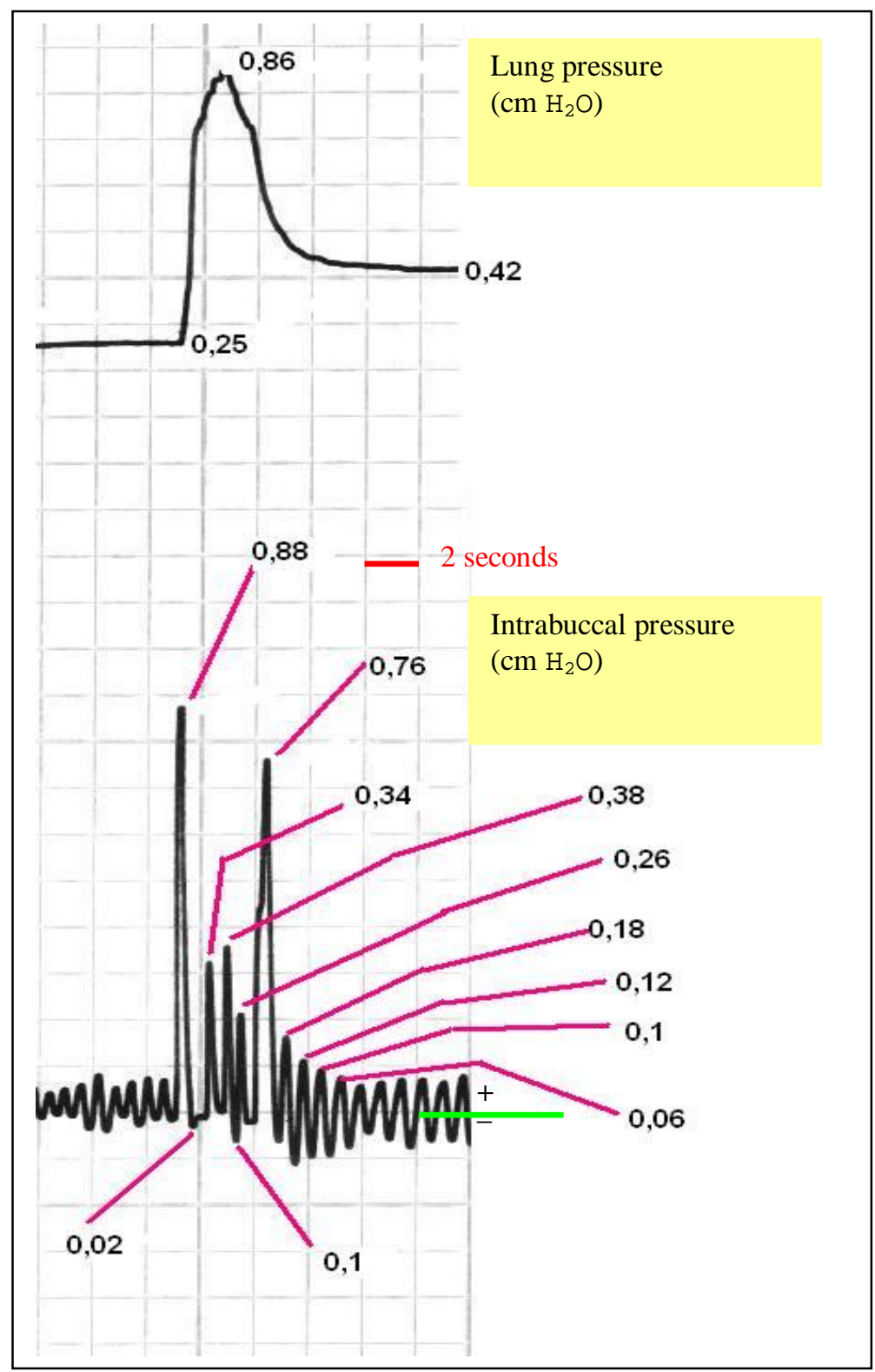

Figure 5- The record shows inflation immediately followed by a lung deflation during a cycle of ventilation, as evidenced by changes in intrabuccal and intrapulmonary pressures $(\mathrm{cm}$ $\mathrm{H}_{2} \mathrm{O}$ ). The pressure values are indicated by numbers and arrows. The green bar is equivalent to atmospheric pressure $\left(1 \mathrm{~cm} \mathrm{H}_{2} \mathrm{O}\right)$.

During buccal cycles, the intrabuccal pressures and intrapulmonary remained uniform. Intrabuccal pressures fluctuated continuously above and below atmospheric values, equal to $0.06 \mathrm{~cm} \mathrm{H}_{2} \mathrm{O} \pm 0.007$ (mean $\pm \mathrm{SEM}$ ), with no statistic differences. With the air trapped in the lungs during the oscillatory cycles, the intrapulmonary pressure remained relatively stable, with a slight decline (Figure 2), equal to $1.0 \pm 0.1 \mathrm{~cm} \mathrm{H}_{2} \mathrm{O}$ (mean $\pm \mathrm{SEM}$ ). During pulmonary 
cycles, pressures reached positive values $0.65 \pm 0.1 \mathrm{~cm} \mathrm{H}_{2} \mathrm{O}$ (mean $\pm \mathrm{SEM}$ ). But the subatmospheric pressure remained with the same amplitudes of the oscillatory cycles.

Intrapulmonary pressures ranging from 0.25 to $1.84 \mathrm{~cm}$ of water, with a mean \pm SEM equal to $1.2 \pm 0.1 \mathrm{~cm} \mathrm{H}_{2} \mathrm{O}$, and is always above the intrabuccal pressure, with statistic significance.

Measures of inspiratory and expiratory volumes through the nostrils.- The records of inspiratory and expiratory flows and their respective volumes were obtained from a pneumotachograph mask, during cycles of buccal and lung ventilation of the toad rhinella schneideri and are shown in figures 6, 7, 8 and 9.

In figure 6 we can see two sequences of flow achieved during the buccal cycles (with a mean \pm sem of $0.7 \pm 0.2 \mathrm{ml}$ ). observe that buccal ventilation could be increased briefly with larger flows. the inspiratory and expiratory flows were uniform through the nostrils even in large flows.

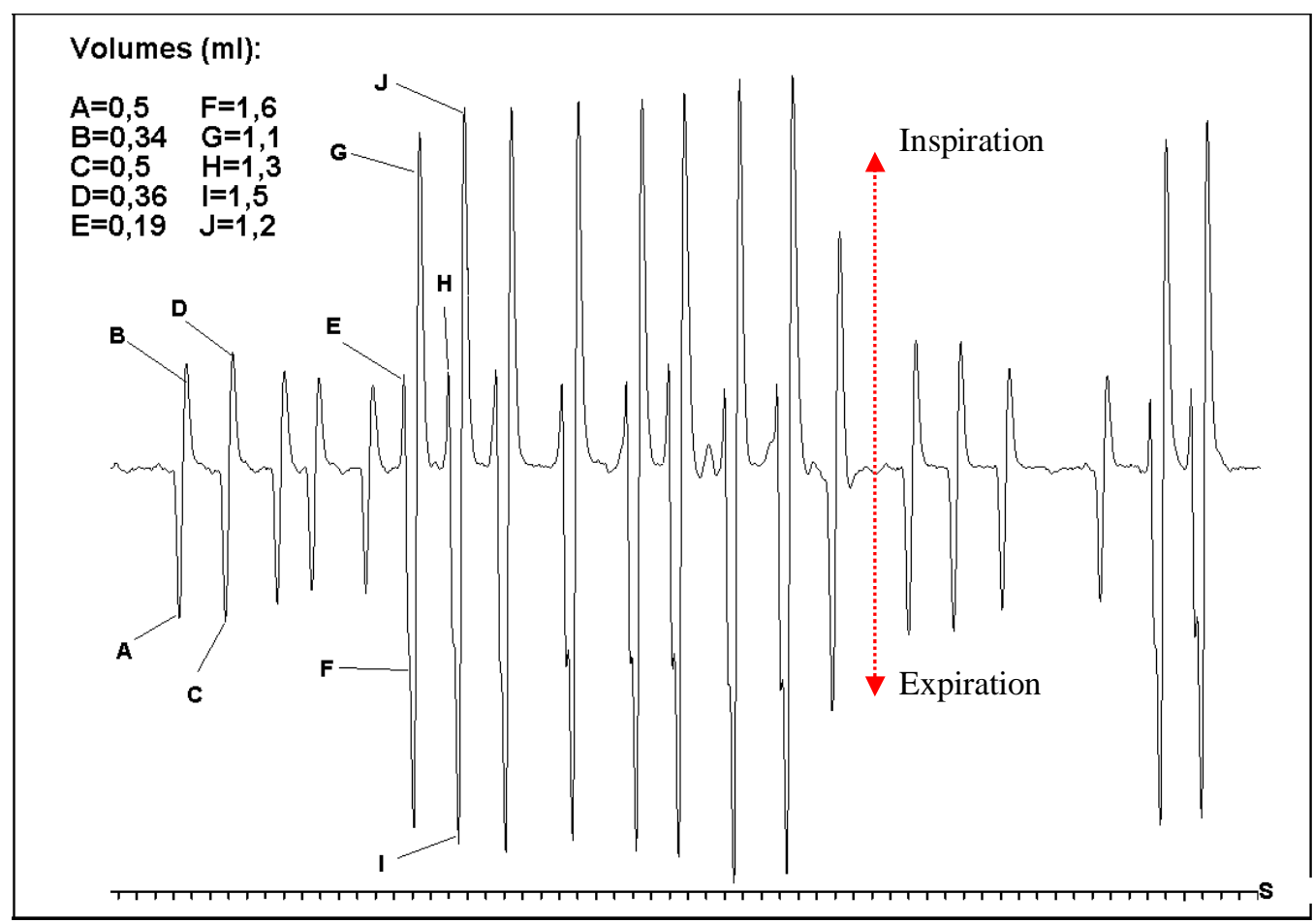

Figure 6- The record shows inspiratory and expiratory flows and their respective volumes obtained from pneumotachography mask during buccal cycles. The ventilatory volumes are indicated by letters and arrows and their respective values in the legends. The horizontal bar (s) below the record corresponds to the interval in seconds. 
In figures 7, 8 and 9, we can see a large flow resulting from a lung deflation, called for us to peak of the first expiration after apnea. these flows show greater volume in the beginning of a pulmonary cycle, interrupting abruptly the mouth movements. peak expiratory was accompanied by an increase in respiratory rate, and were not observed inspiratory flow volumes equivalent to these peaks. the tidal volumes increase only slightly.

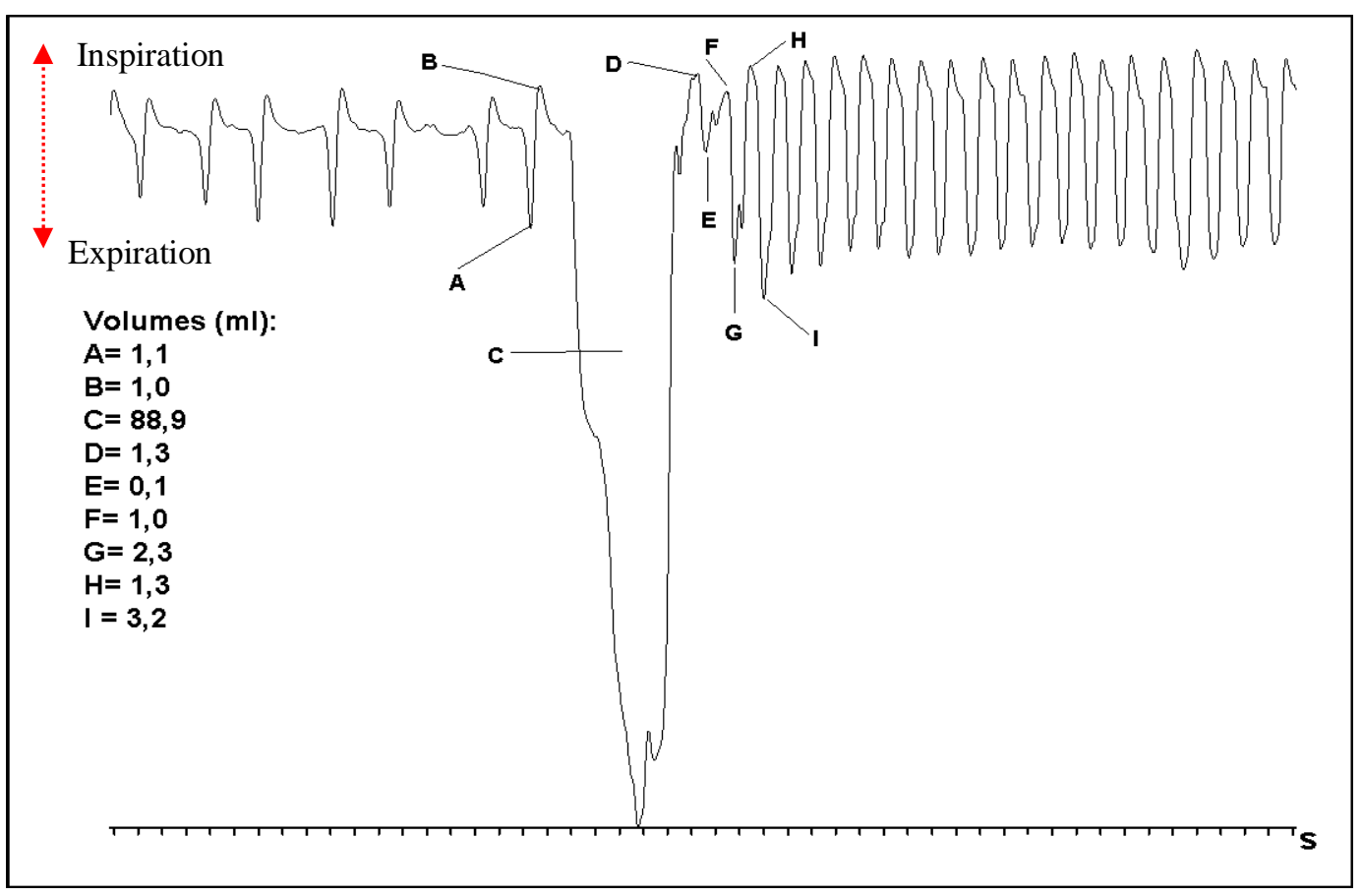

Figure 7- The record shows inspiratory and expiratory flows and their respective volumes, obtained from a pneumotachograph mask, during the transition from buccal to lung cicle. The peak expiratory flows, a large volume, were accompanied by an increase in respiratory rate. The tidal volumes were hardly changed. The ventilatory volumes are indicated by letters and arrows and their respective values in the legends. The horizontal bar (s) below the record corresponds to the interval in seconds. 


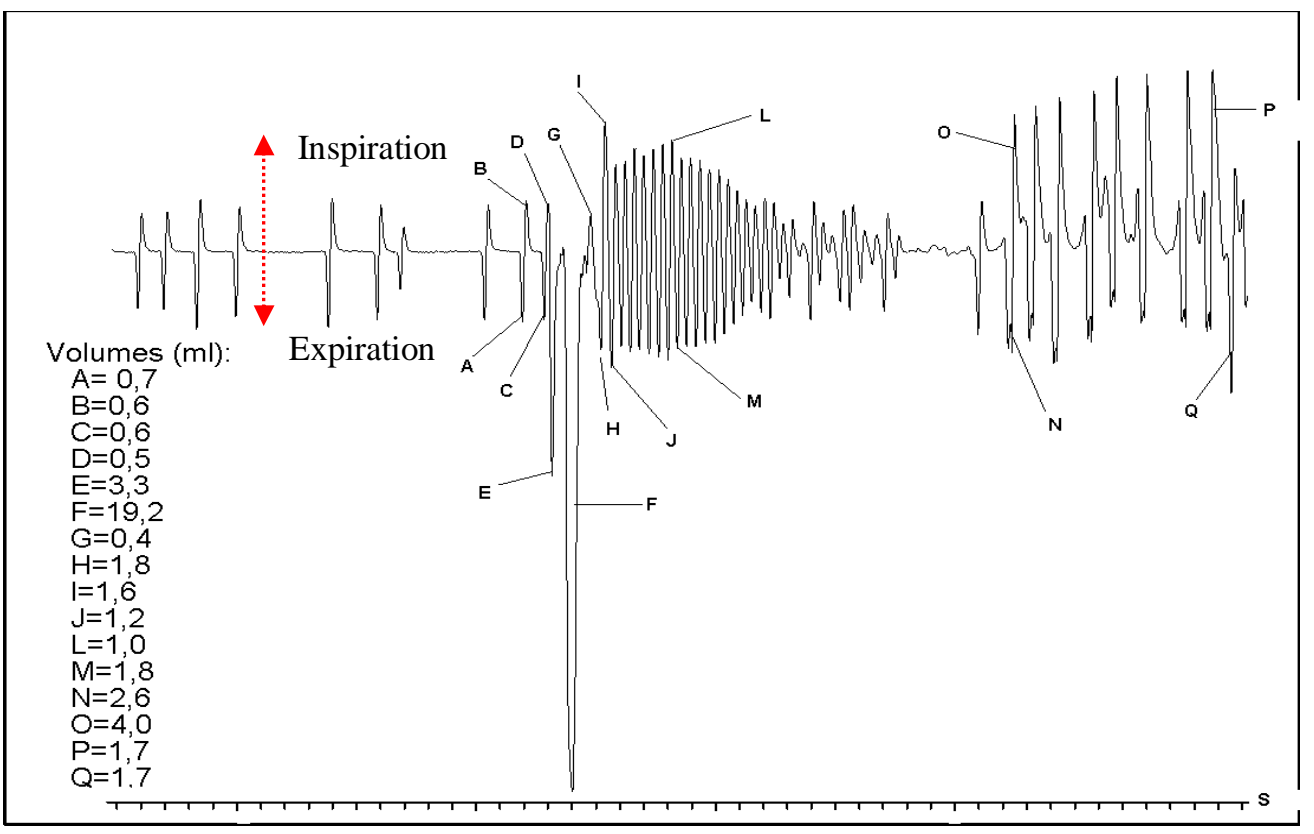

Figure 8- The record shows inspiratory and expiratory flows and their respective volumes, obtained from a pneumotachograph mask, during the transition from buccal to lung cicle. The peak expiratory flows, a large volume, were accompanied by an increase in respiratory rate. The tidal volumes were hardly changed. The ventilatory volumes are indicated by letters and arrows and their respective values in the legends. The horizontal bar (s) below the record corresponds to the interval in seconds.

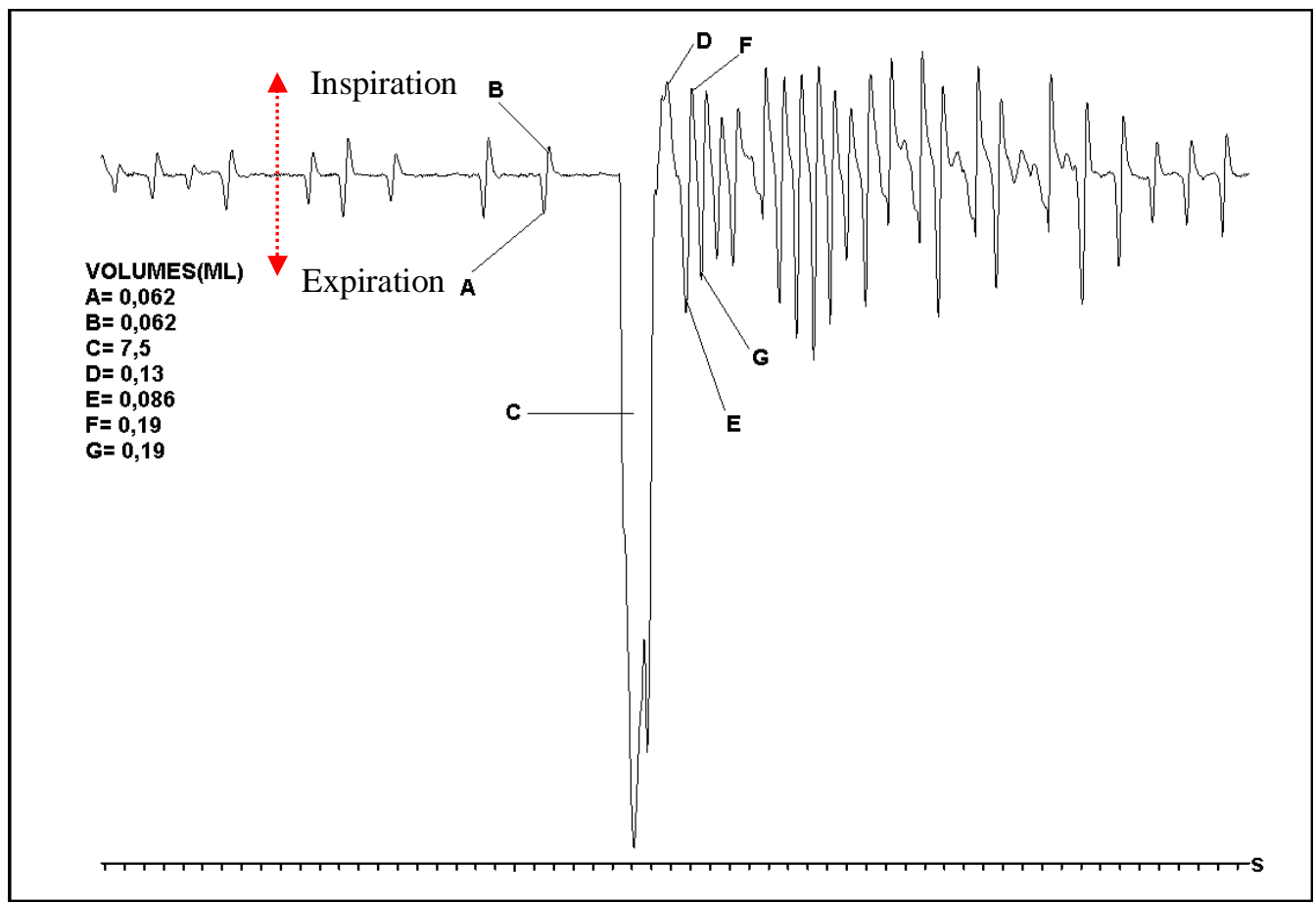

Figure 9- The record shows inspiratory and expiratory flows and their respective volumes, obtained from a pneumotachograph mask, during the transition from buccal to lung cicle. The peak expiratory flows, a large volume, were accompanied by an increase in respiratory rate. The tidal volumes were hardly changed. The ventilatory volumes are indicated by letters and arrows and their respective values in the legends. The horizontal bar (s) below the record corresponds to the interval in seconds. 
Ventilatory measures obtained by pneumotachography.- The mean \pm SEM of ventilatory measures, obtained by pneumotachography such as buccal ventilation, total pulmonary ventilation, effective ventilation, frequencies of buccal and lung ventilation and tidal volume are presented in Table 1.

Table 1 - Ventilatory measures obtained by pneumotachography: buccal ventilation $\left(\mathrm{V}_{\mathrm{EB}}\right)$, total pulmonary ventilation $\left(\mathrm{V}_{\mathrm{EL}}\right)$, effective ventilation $\left(\mathrm{V}_{\mathrm{EF}}\right)$, Frequency of lung and buccal ventilation, Tidal volume. Mean \pm SEM

\begin{tabular}{|c|c|c|}
\hline & Média & SEM \\
\hline $\mathrm{V}_{\mathrm{EF}}\left(\mathrm{ml}\right.$ BTPS. $\left.\mathrm{min}^{-1} \cdot \mathrm{kg}^{-1}\right)$ & $7,0^{*}$ & 1,3 \\
\hline $\mathrm{V}_{\mathrm{EL}}(\mathrm{ml}$ BTPS.min & \\
\hline $\mathrm{V}_{\mathrm{EB}}\left(\mathrm{ml}\right.$ BTPS. $\left.\mathrm{kg}^{-1}\right)$ & 12,1 & 0,6 \\
\hline Frequency of lung ventilation $\left(\mathrm{min}^{-1}\right)$ & $164,3^{*}$ & 2,2 \\
\hline Frequency of buccal ventilation $\left(\mathrm{min}^{-1}\right)$ & 5,8 & 0,4 \\
\hline Tidal volume in buccal cicles (ml BTPS.kg & \\
\hline
\end{tabular}

$\left.{ }^{*}\right)$ significant difference in pulmonary ventilation $(p<0.05), n=6$. Kruskal-Wallis, Dunn. (\#) Significant difference in respiratory lung. Paired t test $(p<0.05), n=6$.

Buccal ventilation, lung ventilation and effective ventilation show significantly differences. The buccal ventilations were significantly larger than the lung, as already noted in the records of pressure and ventilatory pattern, confirming that the buccal cycles are much more frequent than the lung ventilations. The effective ventilation shows a ventilatory pattern efficient.

The frequency of buccal ventilation was almost 12 times greater than the lung ventilation, confirming the records of pressures and flows.

The tidal volumes also confirm the flow records, showing relatively small during buccal cycles.

Measures of pulmonary $\mathrm{O} 2$ extraction (E1 and E2.).- Regarding the equations E1 and $\mathrm{E} 2$, representing the pulmonary extraction of $\mathrm{O}_{2}$, the consistency of $\mathrm{E} 1$ was confirmed by $\mathrm{E} 2$, since both result in same values with means \pm SEM equal to $17.3 \pm 2.8 \%$. An extraction of $\mathrm{O}_{2}$ low when compared to other animals (Dejours, 1981). The mean \pm SEM ratio of pulmonary respiration $\left(R_{E}\right)$, used in equation $E 2$, was equal to $0.48 \pm 0.07$. 


\section{DISCUSSION}

The records of buccal and intrapulmonary pressures confirmed the role of the buccal cavity to mediate between his own and ventilation of the lungs in the toad Rhinella schneideri, as observed by other authors.

Foxon (1964) suggested that the buccal ventilation cycles have only olfactory function, but we suggest that something else would be behind the mouth movements. Even thought small tidal volumes $\left(2.4 \pm 0.4 \mathrm{ml} \mathrm{BTPS} . \mathrm{kg}^{-1}\right)$ were observed through the nostrils during the cycles, these are present in high frequency $\left(68.5 \pm 1.6 \mathrm{~min}^{-1}\right)$, resulting in high buccal ventilation $\left(164.3 \pm 2.2 \mathrm{ml}\right.$ BTPS. $\left.\mathrm{min}^{-1} \cdot \mathrm{kg}^{-1}\right)$, a fact which should result in high energy cost. The buccal cavity of Rhinella schneideri is very large in proportion to the body $(93.5 \pm$ $\left.0.01 \mathrm{ml} . \mathrm{kg}^{-1}\right)$ (FERNANDES et al., 2005) and we confirmed and observed that buccal cycles are much more frequent than lung, data that corroborate the hypothesis of high energy expenditure.

Vitalis and Shelton (1990) suggested that the buccal cavity could be responsible for renewing the air residual resulting from the last expiration, preparing it for the next cycle lung. Dates of $\mathrm{PO}_{2}$ of buccal cavity $(141.7 \pm 0.8 \mathrm{mmHg})$ obtained for Rhinella schneideri supports the hypothesis of Vitalis and Shelton, they are very close to the atmospheric air of the study area $(145 \mathrm{mmHg})$, confirming that the oral cavity is well ventilated. The expiratory gas often has low $\mathrm{PCO}_{2}$ and we also observed an abrupt increase in buccal ventilation rate after the first expiration in Rhinella schneideri, corroborating in the same way for this hypothesis.

How long would it take for the wash of buccal cavity of possible residual air, coming from lung ventilation? We suggest by ours dates that there is a constant leak of air from the lungs by glottis. A subtle drop in intrapulmonary pressure during buccal cycles corroborated this hypothesis. Ours results corroborate the hypothesis of Jones (1982), who observes the same pattern in the toad Bufo marinus.

Further evidence of this leak came from the observation of movements on the flanks of the animal, suggesting that this leak could be due to compression of the intrapulmonary air by the muscles of the body, a procedure that would force the air against the walls of the lungs and glottis. This could result in leakage of air into the oral cavity and subsequent reduction in intrapulmonary pressure during cycles of mouth. Our results also corroborate the studies of Baker and Smatresk ( 2003 ), who observed decrease in intrapulmonary pressure, and 
movements on the flanks in Bufo marinus. The authors suggested that these movements could be responsible for mixing the intrapulmonary air stagnant during the apnea cycles mouth.

Intrabuccal and intrapulmonary pressures in Rhinella schneideri have shown to be lower than those obtained by other authors. This could reflect differences between species, or different situations during the experiments for each author.

Cycles of pulmonary ventilation begin by abrupt, starting by expiratory flow of greater volume. It was also noted successive peaks of decrease in pressure of buccal cavity. What it should reflect?

One hypothesis is the resistance of the nostrils to the passage of a massive flow briefly, stemming from the sudden opening of the glottis. This flow of the lungs, to enter the buccal cavity find the volume of air in the buccal space itself, raising the pressure in the oral cavity. Thus, this air would be expelled through the nostrils with greater speed. It seems that the buccal cavity at this time serves as a safety valve: a sudden increase in pressure in the buccal cavity in the time interval 2, Figure 1, is accompanied by three successive pulses of elimination of air very fast. The abrupt increase of mouth pressure forces the air against the nostrils that are open at that time, resulting in large expiratory flow.

The procedures of the lungs inflate and deflate them immediately in a partial manner, like a sigh, is observed in some situations (figure 5). In Figure 4, a lung emptying is followed by a subtle and immediate oral pumping air into the lungs.

These patterns could reflect perhaps part of an animal's behavior.

Another hypothesis, which seems more logical, is the renewal of the air that is stored in the lungs. These pumping could contribute to the oxygenation of the lungs, even without large flow of air.

The pumping of air into the lungs by the buccal cavity is for intermittent inspiratory flows, resembling the pattern described by Macintyre and Toews (1976) for the toad Bufo marinus. The nasal flow during the pulmonary cycle of Rhinella schneideri remained without interruption, confirming the results of Jones (1982) and Baker and Smatresk (2003), which suggested that there is no complete closure of the nostrils during pumping air into the lungs.

We don't observe in Rhinella schneideri pattern similar to that described by KruhØffer et al., (1987) and Wang (1994), characterized by several initial expirations, being gradually replaced by inspiration. The data obtained by these authors resulted from animals under conditions of hypoxia, which may have been responsible for such patterns. A small tidal volume during inspiration could contribute to lower air mixture inside the cavity, as suggested 
by Jones (1982) and Fernandes et al., (2005) in the analysis of the Jet Stream model for the toad Rhinella schneideri.

Like in other amphibians (DEJOURS, 1981), we observed a low lung oxygen extraction. We suggest the animal meets this low lung oxygen extraction by high pulmonary ventilation. This hypothesis was reflected analyzing $\mathrm{VO}_{2}$ related to lung oxygen extraction according to the equation described by Dejours (1981):

$\left[\mathrm{V}_{\mathrm{O} 2}=\mathrm{V}_{\mathrm{E}} \cdot \mathrm{E}_{\mathrm{O} 2} \cdot \mathrm{CI}_{\mathrm{O} 2} \rightarrow \mathrm{E}_{\mathrm{O} 2}=\mathrm{V}_{\mathrm{O} 2} /\left(\mathrm{V}_{\mathrm{E}} \cdot \mathrm{CI}_{\mathrm{O} 2}\right)\right] ; \mathrm{E}_{\mathrm{O} 2}=\operatorname{extração~de~} \mathrm{O}_{2}(\%) ;$

$\mathrm{V}_{\mathrm{O} 2}=$ consumo de $\mathrm{O}_{2}\left(\mathrm{ml}\right.$ BTPS. $\left.\min ^{-1} \cdot \mathrm{kg}^{-1}\right) ; \mathrm{V}_{\mathrm{E}}=$ ventilação pulmonar

$\left(\mathrm{ml} . \mathrm{BTPS} . \mathrm{min}^{-1} \cdot \mathrm{kg}^{-1}\right) ; \mathrm{CI}_{\mathrm{O} 2}=$ concentração fracional inspirada de $\mathrm{O}_{2}(\%)$

With $\mathrm{E}_{\mathrm{O} 2}=17,3 \% ; \mathrm{V}_{\mathrm{E}}=12,1 \mathrm{ml}$.BTPS. $\min ^{-1} \cdot \mathrm{kg}^{-1} ; \mathrm{CI}_{\mathrm{O} 2}=0,21$ we obtained

$\mathrm{V}_{\mathrm{O} 2}=43,9 \mathrm{ml} \mathrm{BTPS}$. $\min ^{-1} \cdot \mathrm{kg}^{-1}$. This value is consistent with that obtained by Glass et al (1997) for Rhinella schneideri at $25^{\circ} \mathrm{C}\left(44.4 \pm 5.1 \mathrm{ml} \mathrm{BTPS.kg.}{ }^{-1} \cdot \mathrm{min}^{-1}\right)$.

It became clear why the low lung extraction of $\mathrm{O}_{2}$ of the animal should be compensated by increased pulmonary ventilation.

With this study we contributed to clarify a bit more this complex ventilatory pattern between anurans.

\section{ACKNOWLEDGMENTS}

We thank CNPq and FAEPA, for financial support. IBAMA provided the Zoological Permanent Collection Material License (with number 1015-3), in February 19, 2009.The animals used in this study were treated ethically with appropriate treatments according with Guidelines for Use of Live Amphibians and Reptiles in Field Research.

\section{LITERATURE CITED}

BAKER,C.F.C.; SMATRESK, N.J. Ventilatory behaviors of the toad Bufo marinus revealed by coherence analysis. Brazilian Journal of Biology, v.63, n.1, p. 27-34, 2003.

BRETT, S.S.; SHELTON, G. Ventilatory mechanisms of the amphibian, Xenopus laevis: role of the bucal force pump. Journal of Experimental Biology, v.80, p.125-269, 1979. 
BOUTILIER, R. G. Characterization of the intermittent breathing pattern in Xenopus laevis. Journal of Experimental Biology, v.110, p. 291-309, 1984.

DE JONGH, H. J, AND C. GANS. On the mechanism of respiration in the bullfrog Rana catesbeiana: A reassessment. Journal of Morphology, v.127, p. 259-290, 1969.

DEJOURS, P. Principles of comparative respiratory physiology. North Holland: Elsevier, Biochemical Press, 1981.

FERNANDES, M.S.; GIUSTI, H.; GLASS, M.L. An assessment of dead space in pulmonary ventilation of the toad Bufo schneideri. Comparative Biochemistry and Physiology, Part A 142, p.446-450, 2005.

FOXON, G.E.H. Blood and respiration: in physiology of amphibia. New York: Academic Press., 1964.

GANS, C.; DE JONGH, H.J.; FARBER, J. Bullfrog (Rana catesbeiana) ventilation: how does the frog breathe? Science, v.163, n.872, p.1223-1225, 1969 mar. 14.

\section{HLASTALA, M.P.; BERGER, A J. PHYSIOLOGY OF RESPIRATION. OXFORD: UNIVERSITY PRESS, 2001.}

\section{HUGHES, G.M. THE PHYSIOLOGY OF VERTEBRATE RESPIRATION. LONDON: HEINEMAN, 1963.}

Jones, D.R. 1972. Anaerobioses and the oxygen debt in an anuran amphibian.

Rana esculenta. Journal of Comparative Physiology A, 77: 356-382.

Jones, R.M.1982. How toads breathe: control of air flow to and from the lungs by the nares in Bufo marinus. Respiratory Physiology, 49: 251-265.

Kruh $\varnothing$ ffer, M., M.L. Glass, and A.S. Abe. 1987. Control of breathing in an amphibian Bufo paracnemis: effects of temperature and hypoxia. Respiratory Physiology, 69: 267-275.

Macintyre, D.H., and D.P. Toews. 1976. The mechanics of lung ventilation and the effects of hypercapnia on respiration in Bufo marinus. Canadian Journal of Zoology, 54: 1364-1374.

Romer, A.S. 1985. Anatomia Comparada dos Vertebrados. Atheneu Editora. São Paulo.

Shelton, G., and R.G. Boutilier. 1982. Apnoea in amphibians and reptiles. Journal of Experimental Biology ,100: 245-273.

Vitalis, T.Z., and G. Shelton. 1990. Breathing in Rana pipiens: the mechanism of ventilation. Journal of Experimental Biology, 154: 537-556.

Wang, T. 1994. Measurement of ventilatory responses in the toad Bufo marinus: A comparison of pneumotachography and buccal pressures. Comparative Biochemistry and Physiology Part A: Physiology, Volume 109, Issue 3, November 1994, Pages 793- 798

West, J.B. 1995. Respiratory Physiology. Willians and Wilkins. Baltimore. 
West, N.H., and D.R. Jones.1975. Breathing movementes in the Rana pipiens.I. The mechanical events associated with lung and buccal ventilation. Canadian Journal of Zoology, 53: 332-334.

Yeager, D.P., G.R. Ultsch. 1989. Physiological regulation and conformation:

a BASIC program for the determination of critical points. Physiological zoology, 62, 888907. 